\title{
Lu Weijing, True to Her Word: The Faithful Maiden Cult in Late Imperial China.
}

\section{Kathryn Edgerton-Tarpley}

\section{Q OpenEdition}

1 Journals

Édition électronique

URL : http://journals.openedition.org/chinaperspectives/4865

DOI : 10.4000/chinaperspectives.4865

ISSN : 1996-4617

Éditeur

Centre d'étude français sur la Chine contemporaine

\section{Édition imprimée}

Date de publication : 1 septembre 2009

ISSN : 2070-3449

\section{Référence électronique}

Kathryn Edgerton-Tarpley, « Lu Weijing, True to Her Word: The Faithful Maiden Cult in Late Imperial China. », China Perspectives [En ligne], 2009/3 | 2009, mis en ligne le 16 octobre 2009, consulté le 23 septembre 2020. URL : http://journals.openedition.org/chinaperspectives/4865 ; DOI : https://doi.org/ 10.4000/chinaperspectives.4865

Ce document a été généré automatiquement le 23 septembre 2020.

(C) All rights reserved 


\title{
Lu Weijing, True to Her Word: The Faithful Maiden Cult in Late Imperial China.
}

\author{
Kathryn Edgerton-Tarpley
}

1 In True to Her Word: The Faithful Maiden Cult in Late Imperial China, Weijing Lu establishes the historical significance of the social phenomenon in which, over the course of China's late imperial period, an increasing number of young women responded to the death of their fiancés by either committing suicide to join them in death or remaining celibate and living out the rest of their lives as their widows. Lu's book contributes to a growing body of recent scholarship that problematises earlier perspectives on the victimisation and insignificance of women in imperial China.

2 Judging by the relatively small number of faithful maidens -- 291 reported in the Ming dynasty (1368-1644) and 5,441 honoured by the court in the first 200 years of the Qing (1644-1850) out of a population that grew from roughly 65 million to 400 million during that period -- Lu's contention that the faithful maiden cult "was not marginal to but one of the centrepieces of late imperial history" (247) may seem a bit overstated. Nevertheless, her book offers compelling evidence that faithful maidens, who have received far less attention from modern historians than the contemporaneous cult of widow chastity, "figured just as prominently" in the literati imagination as the far more numerous chaste widows, and indeed "shaped the intellectual agenda" of Ming and Qing literati in important ways. Drawing on central government records of court honours (jingbiao) conferred upon faithful maidens, scholarly debates over the cult, depictions of faithful maidens in local gazetteers, biographies, and popular dramas, and, most interestingly, poems written by faithful maidens and their female friends, True to Her Word also offers a woman-centred narrative of late imperial history.

The first section of Lu's book contextualises the formation and expansion of the faithful maiden cult by linking its rise to broader intellectual, social, and political trends of the late imperial era. The cult first surfaced in the thirteenth century, but did not take a firm hold until the early sixteenth century. Lu finds that the mid-Ming emphasis on 
moral cultivation, combined with polarising fights between eunuchs and officials at court and anxiety about social disorder caused by rapid economic growth, led to "an age of moral heroism" that extolled extreme behaviour such as the self-mutilation and suicide practiced by faithful maidens. Literati championing of faithful maidens intensified during the Ming-Qing transition of the seventeenth century. Traumatised by the collapse of the Ming at the hands of alien conquerors, some Han literati chose to end their lives with the dynasty, while others worked for Ming restoration or abandoned their political careers altogether rather than serve the Manchus. To them, the spectacle of a young woman committing suicide in order to remain faithful to a deceased fiancé whom she may never even have met came to represent "the ultimate moral spirit of the era" (49). While the importance of the faithful maiden as a "political embodiment of loyalty" faded away after the early Qing, the number of faithful maiden cases increased steadily during the eighteenth and nineteenth century. Lu traces this to the Qing court's active support of the cult, local-level and literati recognition of faithful maidens, and arches, tombs, and shrines built to honour such women.

4 Part two, the richest and most innovative section of the book, uses poems written by faithful maidens and biographies of them to call into question conventional depictions of powerless Chinese daughters. Lu examines the crucial question of why young women chose to die for or remain faithful to deceased fiancés, especially in light of the fact that their decisions usually went against the wishes of both their natal and marital families. The practice of child betrothal and the prolonged interval between betrothal and marriage played an important explanatory role. When a girl became engaged in early childhood, states $\mathrm{Lu}$, she grew up thinking of herself as a member of her fiancé's family and often developed an emotional attachment to her future husband. Moreover, women in late imperial China grew up in a society that championed self-sacrifice and heroism in fulfilling one's honour-bound duty, or yi. Upon hearing the shocking news of a fiancé's death, then, young women from many different regions and social classes felt that obeying their parents' wishes to marry someone else would be an act of betrayal that forsook both the honour-bound duty owed to the deceased fiancé and emotional attachment to him. A girl who chose faithful maidenhood either committed suicide to join her fiancé, or married into her deceased fiancés home through a spirit wedding, sought to adopt an heir from his lineage to carry on his family line, and lived out the rest of her life as a celibate widow. Faithful maidens faced difficult lives characterised by loneliness, self-imposed asceticism and seclusion, unfulfilled sexual needs, and frequent disputes over adoption and property. At the same time, $\mathrm{Lu}$ demonstrates that the faithful maiden's "pivotal status as a symbol of female virtue" (210) provided these women with a rich source of social capital used effectively by many young women to gain authority in the marital family, to fight for revenge and justice, and to motivate local officials and literati to intervene on their behalf.

In spite of the steady expansion of the faithful maiden cult, the phenomenon remained highly controversial throughout the late imperial era. The third section of True to Her Word analyses the heated debate over the ritual validity of the cult, and in the process provides an insightful overview of areas of contention in Qing evidential scholarship. Critics of faithful maidens, who had a clear textual edge over their rivals, drew on descriptions of classical marriage rituals recorded in the Book of Rites to argue that a woman was not considered a member of her husband's family until every step of the marriage rites had been completed. A betrothed girl whose fiancé died before the wedding was not yet a wife, they explained, so encouraging her parents to arrange for 
her to marry another man was in accordance with ancient ritual. Allowing her to die or remain celibate for her dead fiancé violated those rituals, put the husband-wife relationship in jeopardy, and resulted in unfilial behaviour. Literati defenders of faithful maidens, on the other hand, "reinterpreted or even twisted the classics" to support a practice they found heroic and morally inspiring (214). Some scholars went so far as to question the authority of ancient rituals by asserting that because social institutions in their day differed significantly from those in ancient times, some classic rituals were no longer applicable.

Lu's conclusion addresses the demise of the faithful maiden cult. She finds that although the cult persisted into the early Republican period, faithful maidens began to lose their symbolic appeal when the particular social and cultural environment that had nurtured them disappeared. The radical leaders of the New Culture movement of 1915-1921 attacked the phenomenon as representative of Confucian gender repression, states $\mathrm{Lu}$, and the cult came to an end during that movement. Especially in light of her nuanced analysis of the cult's origins and expansion, Lu's brief account of its downfall is overly abrupt. A fuller discussion is needed of how, why, and whether the phenomenon suddenly disappeared during the New Culture movement, especially since the new Republican government went to the trouble of specifying its own criteria for honouring faithful maidens as late as 1917. Some attempt to explain why the faithful maiden cult, in contrast to the cult of widow chastity, was largely forgotten by both twentieth-century Chinese revolutionaries and modern historians would also be beneficial. On the whole, though, by putting the faithful maiden cult back on the map, examining gendered responses to alien conquests, and getting at the crucial question of how young women understood their actions and self-identity, True to Her Word makes an important contribution to gender studies and late imperial Chinese history. 